\title{
Purification and protein composition of oil bodies from Brassica napus seeds
}

Pascale JOLIVET ${ }^{1}$

Kathleen TAILLIART ${ }^{1}$

Céline BOULARD ${ }^{1}$

Nathalie NESI ${ }^{2}$

Thierry CHARDOT $^{1}$

${ }^{1}$ UMR Inra Ina-PG Chimie Biologique,

Centre de Biotechnologie Agro-Industrielle, Thiverval-Grignon, 78850, France

<jolivet@grignon.inra.fr>

2 UMR Inra AgroCampus Rennes Amélioration des Plantes et de Biotechnologies Végétales,

Domaine de la Motte au Vicomte,

Le Rheu cedex, 35653, France

\begin{abstract}
Seed oil bodies are intracellular particles to store lipids as food reserves in oleaginous plants. Description of oil body-associated proteins of Arabidopsis thaliana has been recently reported whereas only few data are available in the case of rapeseed. Oil bodies have been prepared from two double-low varieties of Brassica napus seeds, a standard variety (Explus) and an oleic variety (Cabriolet). Oil bodies have been purified using floatation technique in the successive presence of high salt concentration, detergent or urea in order to remove non-specifically trapped proteins. The integrity of the oil bodies has been verified and their size estimated. Their protein and fatty acid contents have been determined. The proteins composing these organelles were extracted, separated by denaturing gel electrophoresis, digested by trypsin and their peptides were subsequently analyzed by liquid chromatography-tandem mass spectrometry. Protein identification was performed using Arabidopsis thaliana protein sequence database and a collection of Expressed Sequence Tag (EST) of Brassica napus generated from the framework of the French plant genomics programme "Genoplante". This led to the identification of a limited number of proteins: eight oleosins showing a high similarity each other and representing up to $75 \%$ of oil body proteins, a $11 \beta$ hydroxysteroid dehydrogenase-like protein highly homologous to the same protein from $A$. thaliana, and only few contaminating proteins associated with myrosinase activity.
\end{abstract}

Key words: Brassica napus, Arabidopsis thaliana, oil bodies, oleosins, protein composition

\section{Introduction}

Oleo proteaginous plants store lipids in oil bodies, composed of a core of triacylglycerols surrounded by a monolayer of phospholipids in which different proteins are inserted. Although the lipid body is a relative simple organelle from a structural point of view, the mechanisms of its biogenesis and degradation remain largely unknown [2]. The increase of rapeseed economical value relies in improving oil extraction while preserving the quality of protein by-products. In fact, efficient oil extraction from rapeseed is rather difficult, by comparison to other seeds (soybean, sunflower) despite similar oil content than sunflower. The process involves high temperature treatments and use of organic solvent. It is important to identify molecular and cellular factors involved in biogenesis of storage seed oil bodies to identify key factors for the stability of these organelles and to develop milder methods for extraction of rapeseed oil. Oil bodies must withstand extremes of desiccation, rehydration, heating and cooling for months before the storage oil can be mobilized following seed germination. Proteins embedded in the phospholipid membrane form an effective resistant surface for dormant and germinating seeds during the environmental extremes [3].

Description of oil body-associated proteins of Arabidopsis thaliana has been recently published [1]. The most abundant proteins found in A. thaliana are (i) four oleosins (S1 to S4) playing a structural role for stabilizing oil bodies, (ii) one caleosin with an hypothetic role in oil body maturation by calcium mediated fusion of microbodies, (iii) one sterol dehydrogenase. In the case of rape, only few data are available. An average diameter of $654 \mathrm{~nm}$ has been reported for oil bodies isolated from the mature seeds of Brassica napus [4]. Two, then three, then four oleosins have been described by Murphy's team showing a higher similarity each other [5-7]. Their transport from the site of synthesis on ribosomes via the endoplasmic reticulum prior to their accumulation on oil bodies has been also reported [8]. More recently, an oil body-associated caleosin isoform has been reported in rape seeds [9].

In this work, we describe the purification and characterization of oil bodies from two double-low varieties of rape seeds, a standard variety (Explus) and an oleic variety (Cabriolet). Their protein complement has been analyzed the most exhaustively as possible. 


\section{Material and methods}

\section{Seeds}

Mature seeds of Brassica napus (hybrid Explus and variety Cabriolet) were a generous gift of Monsanto (Saint-Louis, Missouri, USA). They were characterized by their fresh weight, dry weight and apparent volume estimated by counting the number of seeds filling the same volume of $15 \mathrm{~mL}$.

\section{Oil body purification and characterization}

\section{Purification}

Oil bodies were purified as described by Tzen et al. [10] by floatation using six successive centrifugation steps $\left(10,000 \times g, 4^{\circ} \mathrm{C}, 30 \mathrm{~min}\right)$ in a Kontron Ultracentrifuge equipped with a swinging-bucket rotor. In a typical oil body preparation, $300 \mathrm{mg}$ of fresh weight of seeds were ground 3 times for $30 \mathrm{sec}$ in $5 \mathrm{~mL}$ of $10 \mathrm{mM}$ sodium phosphate buffer $\mathrm{pH}$ 7.5 containing $0.6 \mathrm{M}$ sucrose (buffer 1 ) with a glass Potter and a teflon plunger driven by a Heidolph motor (rate 7). The sample was cooled on ice between each grinding cycle, and the potter was rinsed by $5 \mathrm{~mL}$ of buffer 1. The homogenate was overlaid by one volume of $10 \mathrm{mM}$ sodium phosphate buffer pH 7.5 containing $0.4 \mathrm{M}$ sucrose (buffer 2) and spun. The oil pad on top was collected and dispersed in $10 \mathrm{~mL}$ of $5 \mathrm{mM}$ sodium phosphate buffer $\mathrm{pH} 7.5$ containing $0.2 \mathrm{M}$ sucrose and $0.1 \%(\mathrm{v} / \mathrm{v})$ Tween 20. The emulsion was overlaid by one volume of $10 \mathrm{mM}$ sodium phosphate buffer pH 7.5 and spun. The oil body fraction was resuspended in $10 \mathrm{~mL}$ of buffer 1 additionally containing $2 \mathrm{M}$ sodium chloride, overlaid by one volume of $10 \mathrm{mM}$ sodium phosphate buffer containing $0.25 \mathrm{M}$ sucrose and $2 \mathrm{M}$ sodium chloride and spun. The oil body fraction was resuspended in $5 \mathrm{~mL}$ of $7 \mathrm{M}$ urea and left on a shaker $(60 \mathrm{rpm})$ at $20^{\circ} \mathrm{C}$ for $10 \mathrm{~min}$. Then the suspension was placed in centrifuge tubes, overlaid by one volume of $10 \mathrm{mM}$ sodium phosphate buffer $\mathrm{pH} 7.5$ and spun. The oil body fraction was resuspended in $5 \mathrm{~mL}$ of buffer 1 and then mixed for $10 \mathrm{~min}$ at $20^{\circ} \mathrm{C}$ with $5 \mathrm{~mL}$ of hexane. After centrifugation and removal of the upper hexane layer, the oil body fraction was collected and resuspended in $5 \mathrm{~mL}$ of buffer 1 . In a last step, the resuspension was overlaid by one volume of buffer 2 and centrifuged. The oil body fraction on top was collected (OB), resuspended in a minimal volume of buffer 1 and stored a $4{ }^{\circ} \mathrm{C}$ till further use.

\section{Microscopy}

Nile red (Molecular Bioprobe, Montluçon, France, solution at $1 \mathrm{mg} \mathrm{mL}^{-1}$ in acetone) was added to an aliquot of oil body suspension $(1 / 10, \mathrm{v} / \mathrm{v})$. After $1 \mathrm{~h}$ incubation at $20^{\circ} \mathrm{C}$, oil bodies were observed at $1000 \times$ focus through WIG or WB filters (for fluorescence) with an Olympus BX 51 light microscope equipped with $100 \mathrm{X}$ oil immersion objective. Images were recorded using the Photometrics Cool SNAP software. Oil bodies were also dropped on a copper grid covered with a carbon film after negative staining using 3\% phosphotungstic acid and observed by electronic microscopy (JEOL JEM-100S equipment operating at $80 \mathrm{kV}$ under low illumination)

\section{Light scattering}

Oil bodies were diluted in water (generally $10 \mu \mathrm{L}$ of purified fraction in $500 \mu \mathrm{L}$ ), and their hydrodynamic diameter was determined using a Malvern HPPS particle sizer. We used a lipid particle refraction index equal to 1.46, as determined by Michalski et al. [11] for milk fat globules. Experiments were performed at $20^{\circ} \mathrm{C}$ in a quartz cuvette. Measurements were repeated 3 to 10 times. Standard latex particles $(200 \mathrm{~nm}$, Nanospheres, Duke Scientific, Palo Alto, USA) were dissolved in Milli Q grade ultrapure water (Millipore Corp, Molsheim, France) and used to check measurement accuracy.

\section{Lipid extraction and quantification of seeds and oil bodies}

Overall fatty acid composition and quantity were determined by gas chromatography. The method is based on the transmethylation of acylated and free fatty acids [12].

One seed (near $5 \mathrm{mg}$ ) was ground in $1 \mathrm{~mL}$ of $2.5 \%(\mathrm{v} / \mathrm{v}$ ) sulfuric acid in methanol containing $100 \mu \mathrm{g}$ of heptadecanoic acid. The sample was heated for $90 \mathrm{~min}$ at $80^{\circ} \mathrm{C}$ making sure that no evaporation of solvent occurs. After the addition of $450 \mu \mathrm{L}$ of hexane and $1.5 \mathrm{~mL}$ of water, fatty acid methyl esters were extracted into the organic phase by vigorous shaking. The tubes were centrifuged at low speed ( $500 \mathrm{~g}$ for $5 \mathrm{~min}$ ) to help the two-phases separation. The organic upper phase was diluted $(1 / 10)$ and $1 \mu \mathrm{L}$ was analyzed by gas chromatography using a Girdel 30 chromatograph with a moving needle-type injector at $250^{\circ} \mathrm{C}$ and a bonded silica capillary column with a stationary phase of $90 \%$ biscyanopropyl - 10\% cyanopropyl siloxane (30 m x $0.25 \mathrm{~mm}$ I.D., $0.25 \mu \mathrm{m}$ film thickness, SP-2380 from Supelco, Saint-Quentin Fallavier, France). The carrier gas was helium at an inlet pressure of 1 bar. The column temperature program started at $120^{\circ} \mathrm{C}$, ramping to $210^{\circ} \mathrm{C}$ at $3{ }^{\circ} \mathrm{C} / \mathrm{min}$. The flame ionization detector was at $270^{\circ} \mathrm{C}$. Identification of fatty acid methyl ester (FAME) peaks was based upon retention times obtained for standards (Supelco). The total amount of fatty acids was calculated from the ratio between the sum of FAME peak areas and the heptadecanoic acid methyl ester peak area. Lipids from oil bodies fraction were extracted according to Folch et al. [13], after addition of heptadecanoic acid as internal standard and subjected to methanolysis.

\section{Protein analysis}

\section{Electrophoresis}

Proteins were quantitated with the Folin Cioccalteu reagent [14] using bovine serum albumin as standard. Protein aliquots from oil body fraction were precipitated with 3 volumes of cold acetone at $-20^{\circ} \mathrm{C}$ for $2 \mathrm{~h}$ or overnight. The pellet was dried and resuspended in a dissociation buffer consisting of $62.5 \mathrm{mM}$ Tris- $\mathrm{HCl}(\mathrm{pH} 6.8), 10 \%(\mathrm{v} / \mathrm{v})$ glycerol, $5 \%(\mathrm{v} / \mathrm{v})$ 2-mercaptoethanol, $2 \%(\mathrm{w} / \mathrm{v})$ sodium dodecyl sulfate (SDS) and $0.02 \%$ $(\mathrm{w} / \mathrm{v})$ bromophenol blue. SDS-PAGE (polyacrylamide gel electrophoresis) of proteins was carried out according to Laemmli [15], using 12\% ready to use Nu PAGE polyacrylamide gels (Novex, San Diego). Electrophoresis was run under $100 \mathrm{~V}$ for $180 \mathrm{~min}$ using $50 \mathrm{mM}$ MES (2-[Nmorpholino]ethane sulfonic acid) NuPAGE buffer ( $\mathrm{pH} 7.3)$. Gel was stained with Coomassie blue (G-250) according to Neuhoff and Harold [16]. Molecular weights were estimated with Mark $12^{\mathrm{TM}}$ standard from Novex.

Gels were scanned (300 dpi) using an EPSON Perfection 1200 PHOTO scanner, and the TIFF resulting gels were analyzed using the Image Quant (version 4.2a) software (Molecular Dynamics).

\section{Identification of oil bodies proteins}

Protein bands stained with Coomassie blue were excised from the polyacrylamide gel and stored at $-20^{\circ} \mathrm{C}$. Before trypsin digestion, gel slices were washed for $5 \mathrm{~min}$ with water, dehydrated for $15 \mathrm{~min}$ with acetonitrile and dried by vacuum centrifugation. Proteins were reduced for $30 \mathrm{~min}$ with $150 \mu \mathrm{L}$ of $10 \mathrm{mM}$ dithiothreitol $-0.1 \mathrm{M}$ ammonium bicarbonate at $56^{\circ} \mathrm{C}$ and alkylated in the dark with $100 \mu \mathrm{L}$ of $55 \mathrm{mM}$ iodoacetamide $-0.1 \mathrm{M}$ ammonium bicarbonate for $20 \mathrm{~min}$ at $20^{\circ} \mathrm{C}$. The gel pieces were washed in $0.1 \mathrm{M}$ ammonium bicarbonate, dehydrated with acetonitrile and vacuum dried. Then proteins were digested overnight at $37^{\circ} \mathrm{C}$ with sequencing grade trypsin (EC 3.4.21.4, Roche Diagnostics, Meylan, France) at the concentration of $12.5 \mathrm{mg} \mathrm{L}^{-1}$ in the presence of $25 \mathrm{mM}$ ammonium bicarbonate and $5 \mathrm{mM}$ calcium chloride. The resulting peptides were extracted successively with $5 \%$ formic acid (v/v), acetonitrile/water (50/50, v/v) and acetonitrile. Combined 
extracts were dried and samples were dissolved in 1\% formic acid before liquid chromatography-mass spectrometry analysis.

High performance liquid chromatography was carried out with a Spectra System equipment (Thermo Separation Products, Riviera Beach, USA) comprising a SCM1000 vacuum membrane degasser, P4000 gradient pumps and a manual injector. Volumes of $10 \mu \mathrm{L}$ of samples were loaded onto a reversed-phase BioBasic- 18 column $(1 \times 150 \mathrm{~mm}, 300 \AA$ pore size, $5 \mu \mathrm{m}$ film thickness, Thermo Electron Corporation). The column was

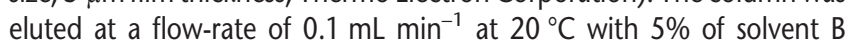
(acetonitrile $+0.1 \%$ formic acid) in $A$ (water $+0.1 \%$ formic acid) for 2 min and then with a linear gradient of B in A from 5 to $45 \%$ over $40 \mathrm{~min}$ then 45 to $95 \%$ over $5 \mathrm{~min}$ before re-equilibration. Eluant from the column was introduced in the electrospray ionisation source of a Thermo Electron LCQ Deca ion-trap mass spectrometer operating in positive ion mode. Instrumental parameters were capillary temperature $280^{\circ} \mathrm{C}$, capillary voltage $30 \mathrm{~V}$, spray voltage $4.5 \mathrm{kV}$, sheath gas flow 80 a.u., auxiliary gas flow 5 a.u. Mass spectra were acquired scanning from m/z 200 to 2000. Ion fragmentation was carried out using a normalized collision energy of 35 arbitrary unit. Peptide ions were analyzed using the data-dependent "triple-play" method as follows: (i) full mass spectrum scan, (ii) ZoomScan (scan of the major ions with higher resolution to determine their charge), (iii) fragmentation of these ions. Protein identification was performed with Bioworks $3.1^{\mathrm{TM}}$ software using Arabidopsis thaliana and Brassica napus protein sequence databases extracted from non-redundant database downloaded from the National Center for Biotechnology Information (NCBI) FTP site. A collection of Brassica napus ESTs that has been generated from developing seeds $(10,15,20,25,40,45$ days after pollination) and anthers in the framework of the French plant genomics programme "Genoplante" (http://www.genoplante.com) was also used during the progress of this work. The collection consists of 39373 ESTs that have been arranged into 13083 unique sequences after clustering and contiging [17]. The unigene set obtained after version 1 of contiging was used for similarity searches. No enzyme specificity was set for the query. The databasesearching algorithm Sequest ${ }^{\mathrm{TM}}$ uses a cross-correlation (Xcorr) and delta correlation (dCN) functions to assess the quality of the match between a tandem mass spectrum and amino acid sequence information in a database. The output data were evaluated in term of (i) trypsin nature of peptides, (ii) Xcorr magnitude up to 1.7, 2.2 and 3.3 for respectively mono-, di- and tri-charged peptides to minimize false positives, (iii) dCN higher than 0.1 .

\section{Results}

\section{Characterization of rape seeds and purified oil bodies}

Explus and Cabriolet seeds were characterized only by little differences (table 1) in weight and size. On the contrary, water content of Cabriolet seeds was slightly higher. Oil bodies were purified from mature seeds and observed under fluorescence or electronic microscopy (figure 1). They proved to be constituted of spheres able to emit fluorescence light upon incubation in the presence of Nile red. The size of oil bodies was estimated using dynamic light scattering or electronic microscopy. Oil bodies from Cabriolet seeds appeared systematically smaller. Protein and fatty acid contents were measured showing a ratio fatty acid/total protein near 1 in the mature seeds and a little enrichment of oil bodies in fatty acid ( $\times 2$ to 3 ). Protein and fat contents of seeds and oil bodies were slightly higher in the case of the standard Explus variety.

Fatty acid composition was determined in seeds and in purified oil bodies by gas chromatography of fatty acid methyl esters using heptadecanoic acid methyl ester as a standard (table 2). It was verified that the seeds of Cabriolet variety were enriched in oleic acid and diminished in linoleic
Table 1. Characteristics of rape seeds and purified oil bodies.

\begin{tabular}{|lccc|}
\hline & & Explus rape & Cabriolet rape \\
\hline Seed & Fresh weight $(\mathrm{mg})$ & 5.03 & 5.10 \\
& Estimated volume $\left(\mathrm{mm}^{3}\right)$ & 7.9 & 8.9 \\
& Water content $(\%)$ & 8.7 & 12.0 \\
& Protein content $(\mathrm{mg} / \mathrm{mg})$ & $0.45 \pm 0.04$ & $0.41 \pm 0.02$ \\
Oil body & $0.43 \pm 0.05$ & $0.39 \pm 0.02$ \\
& Fat content $(\mathrm{mg} / \mathrm{mg})$ & $1095 \pm 212$ & $938 \pm 119$ \\
& Hydrodynamic diameter ${ }^{\mathrm{a}}(\mathrm{nm})$ & $1328 \pm 404$ & $812 \pm 322$ \\
& Microscopy diameter ${ }^{\mathrm{b}}(\mathrm{nm})$ & $132.8 \pm 7.4$ \\
& Protein content $(\mu \mathrm{g} / \mathrm{mg} \mathrm{seed})$ & $38.8 \pm 3.5$ & $33.8 \pm 2.5$ \\
& Fat content $(\mu \mathrm{g} / \mathrm{mg} \mathrm{seed})$ & $100.3 \pm 2.3$ & $95.7 \pm 2.5$ \\
\hline
\end{tabular}

${ }^{a}$ hydrodynamic diameter was estimated using laser dynamic light scattering. ${ }^{b}$ average size was estimated using electronic microscopy by measurements on near 60 oil bodies.

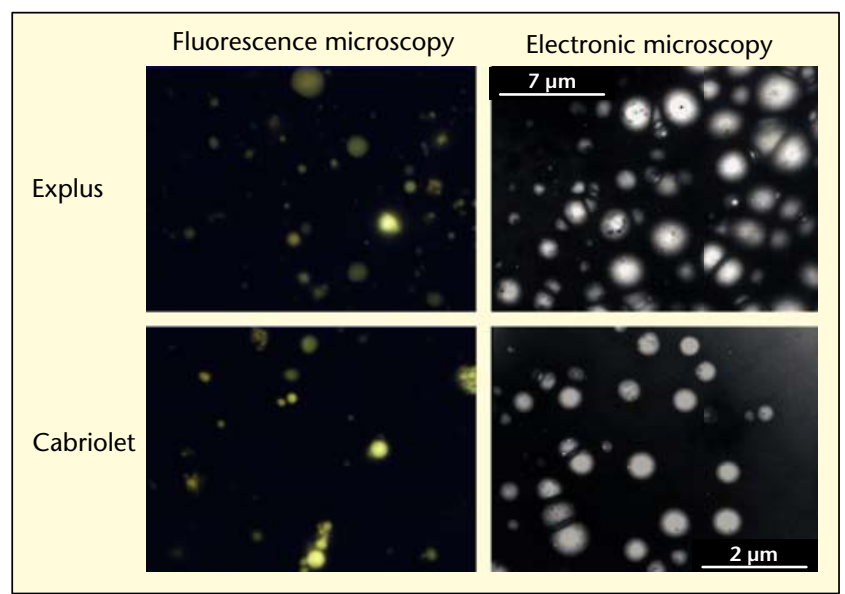

Figure 1. Oil bodies purified from rape seeds were inspected by fluorescence microscopy after staining with the lipophilic dye Nile Red or by electronic microscopy.

Table 2. Fatty acid composition of rape seeds and purified oil bodies.

\begin{tabular}{|lcccc|}
\hline & \multicolumn{2}{c}{ Explus } & \multicolumn{2}{c|}{ Cabriolet } \\
\cline { 2 - 5 } Fatty acid & Seed & Oil body & Seed & Oil body \\
\hline C16:0 & 4.87 & 4.62 & 3.83 & 3.80 \\
C16:1 (n-7) & 0.29 & 0.20 & 0.18 & 0.18 \\
C18:0 & 1.82 & 1.60 & 1.79 & 1.58 \\
C18:1 (n-9) & $\mathbf{6 1 . 4 7}$ & $\mathbf{6 1 . 8 2}$ & $\mathbf{7 3 . 4 8}$ & $\mathbf{7 3 . 8 7}$ \\
C18:2 (n-6) & $\mathbf{2 0 . 5 2}$ & $\mathbf{2 0 . 4 4}$ & $\mathbf{9 . 2 8}$ & $\mathbf{9 . 1 2}$ \\
C18:3 (n-3) & 9.61 & 9.79 & 9.91 & 9.97 \\
C20:0 & 0.40 & 0.46 & 0.41 & 0.40 \\
C20:1 (n-9) & 1.02 & 1.07 & 1.12 & 1.08 \\
\hline
\end{tabular}

Average relative error was near $1.8 \%$.

acid in regards to standard Explus seeds. The same fatty acid composition was recovered in seeds and oil bodies.

\section{Protein composition of purified oil bodies}

The proteins contained in the oil body fraction obtained through the last step of preparation (see Material and Methods) were analyzed by denaturing polyacrylamide gel electrophoresis (figure 2). The two protein patterns were similar for Explus or Cabriolet seeds. Only six different protein bands were clearly visible within the 15-70 kDa range after Coomassie blue staining. Upon scanning of gels and image analysis, an 


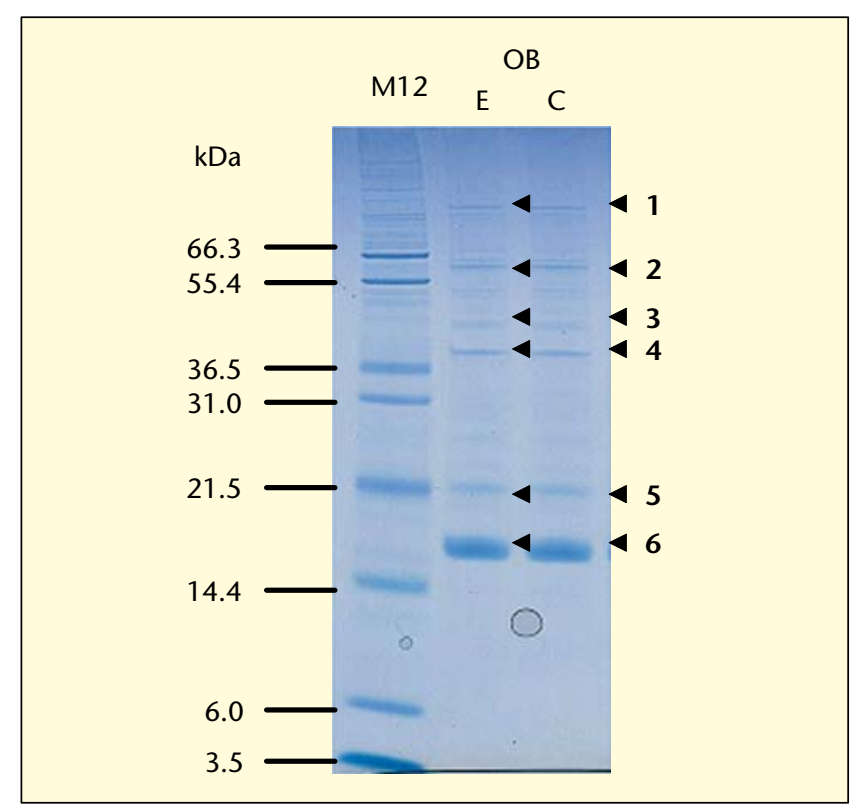

Figure 2. SDS-PAGE of proteins from oil body fraction (OB) purified from Explus $(E$, $10 \mu \mathrm{g}$ ) or Cabriolet (C, $10 \mu \mathrm{g}$ ) seeds. Molecular mass marker was Mark 12 (M12) from Novex. Protein bands were numbered as in table 3.

approximate quantification on the basis of band intensity was obtained (table 3). The protein bands were identified through the analysis of their trypsin peptides with liquid chromatography-tandem mass spectrometry. As Brassica napus genome was not completely sequenced and accessible as public databases, they were identified in part through homology with Arabidopsis thaliana proteins. All the proteins were identified without ambiguity and with a high coverage of the protein sequence. The major proteins present in rape oil bodies were very homologous to integral proteins previously described in $A$. thaliana oil bodies [1]. Interrogation of ESTs database from $B$. napus immature seeds (Genoplante cDNA library) gave the possibility to determine the real protein sequences in B. napus. Eight oleosins were identified in rape oil bodies. One could be distinguished from the others due to its slightly higher apparent molecular mass of $22 \mathrm{kDa}$ (band 5). This oleosin (contig accession number 155968 in the Genoplante database) corresponded only to a partial protein sequence which presented $61 \%$ identity and
$67 \%$ similarity with the N-terminal part of oleosin S4 from A. thaliana and possessed 17 supplementary amino acids. Protein band 6 showing an apparent molecular mass of $17 \mathrm{kDa}$ was the major band and appeared to contain 7 oleosins the molecular mass of which was comprised between 19.3 and $21.5 \mathrm{kDa}$. Four oleosins (BnIll, BnV, napll and contig 155846) presented 82.5 to $86.7 \%$ identity with $A$. thaliana oleosin $S 3$, one oleosin (contig 156118 ) presented $80.8 \%$ identity with $A$. thaliana oleosin $S 1$ and two oleosins (contig 156532 and contig 156533) presented 77.1 to $80.3 \%$ identity with $A$. thaliana oleosin S2.

Besides oleosins, a protein highly similar to the 11- $\beta$-hydroxysteroid dehydrogenase-like protein described in $A$. thaliana was identified. However, only a partial sequence was recovered from ESTs database (235 amino acids against 349 amino acids for $A$. thaliana protein). This partial sequence corresponding to the $\mathrm{N}$-terminal part of the protein presented $89.8 \%$ identity and $96.2 \%$ similarity with $A$. thaliana protein.

Finally, the presence of myrosinase-binding protein, myrosinaseassociated MyAP5 and $\beta$-glucosidase indicated a low contamination of oil body fraction with protein body. However, no storage protein (cruciferins) was identified.

\section{Discussion}

The oil body preparation used repeated and numerous floatation steps. Proteins non-specifically associated with oil bodies were removed by detergent washing, ionic elution and finally urea treatment. Triglycerides from defective oil bodies were removed by hexane extraction. So, only few proteins were visible from oil body fraction and the contamination with proteins involved in the glucosinolate metabolism was relatively low. Seeds and oil body fraction had relatively high protein contents compared to other results. Murphy and Cummins [3] have reported a ratio fatty acid/total protein near 5.7 for oil bodies but they have noticed that total protein was assayed by three different methods and that protein recoveries were relatively low and variable. In fact, they have carried out protein determination on delipidated oil bodies and we have verified in that case a poor protein recovery.

Eight oleosins were identified in purified oil bodies from rape. These oleosins show a high similarity with $A$. thaliana oleosins. However, oppositely to $A$. thaliana oleosins, they were not resolved under SDSPAGE due to their very similar molecular mass, except for rape oleosin S4. Rape oleosins were always heavier than the $A$. thaliana corresponding ones except for oleosin $\mathrm{S} 2$ the molecular mass of which was similar for $B$. napus and $A$. thaliana. Only four oleosins were described in rape by

Table 3. Identified proteins in oil bodies purified from Brassica napus mature seeds.

\begin{tabular}{|c|c|c|c|c|c|c|c|}
\hline Band & $\begin{array}{c}\text { Relative } \\
\text { intensity (\%) }\end{array}$ & Identified protein & $\begin{array}{c}\text { Apparent } \\
\text { molecular } \\
\text { weight (kDa) }\end{array}$ & $\begin{array}{l}\text { Sequence } \\
\text { molecular weight } \\
\text { (kDa) }\end{array}$ & $\begin{array}{c}\text { Sequence } \\
\text { coverage }(\%)\end{array}$ & pl & $\begin{array}{l}\text { A. thaliana } \\
\text { orthologues }\end{array}$ \\
\hline 1 & 2.6 & Myrosinase-binding protein & 88 & 99.404 & 6.8 & 5.5 & \\
\hline 2 & 6.4 & $\beta$-glucosidase & 62 & 56.283 & 5.8 & 6.2 & At3g03640 \\
\hline 3 & 4.4 & Myrosinase-associated MyAP5 & 46 & 41.797 & 31.3 & 8.5 & \\
\hline 4 & 9.4 & $\begin{array}{l}\text { 11- } \beta \text {-hydroxysteroid } \\
\text { dehydrogenase-like }\end{array}$ & 40 & 40 & 22.1 & 6.1 & At5g50600 \\
\hline 5 & 10.7 & contig 155968 & 22 & 23.024 & 28.6 & 9.1 & At5g $40420 / 54$ \\
\hline \multirow[t]{7}{*}{6} & 64.0 & $\mathrm{BnV}$ & 17 & 20.286 & 49.7 & 9.2 & At $4 \mathrm{~g} 25140 / \mathrm{S3}$ \\
\hline & & BnIII & & 21.540 & 19.0 & 9.3 & At $4 \mathrm{~g} 25140 / \mathrm{S3}$ \\
\hline & & Napll & & 19.349 & 53.7 & 9.6 & At $4 \mathrm{~g} 25140 / \mathrm{S3}$ \\
\hline & & contig 155846 & & 19.515 & 47.2 & 9.2 & At $4 \mathrm{~g} 25140 / \mathrm{S3}$ \\
\hline & & contig 156118 & & 20.777 & 23.8 & 8.1 & At3g01570/S1 \\
\hline & & contig 156532 & & 20.002 & 46.3 & 9.1 & At3g27670/S2 \\
\hline & & contig 156533 & & 19.880 & 25.5 & 6.9 & At3g27670/S2 \\
\hline
\end{tabular}


Murphy's team [5, 18-20]. BnV, Bnlll and napll were recovered in our experiments and it appeared that EST 156533 corresponded to napl described only partially by Murphy [18]. Then we observed four supplementary oleosins. Brassica napus is a natural hybrid between $B$. oleracea and $B$. campestris and in consequence, it is not surprising that $B$. napus contains many more oleosins than $A$. thaliana the genome of which is the simplest in the cruciferae family.

Oleosins contain three distinct structural domains, a central hydrophobic anchoring domain, highly conserved and containing no cleavage site for trypsin digestion, and two $\mathrm{N}$ - and $\mathrm{C}$ - terminal amphipathic domains. Recovered peptides through liquid chromatography-tandem mass spectrometry analysis belonged to the two amphipathic domains of the oleosins. The N-terminal part of B. napus oleosin 54 was enriched in glycine: 20 glycine residues, among 64 amino acids for $\mathrm{N}$-terminal part, instead of 11 glycine residues, among 47 amino acids for $\mathrm{N}$-terminal part in A. thaliana oleosin S4. This fact increases the hydrophobic character of $\mathrm{N}$-terminal domain of rape oleosin $\mathrm{S4}$.

A protein highly homologous to sterol dehydrogenase from $A$. thaliana was identified. It is also highly similar to Sesamum indicum sterol dehydrogenase sop2 (65\% identity and $83 \%$ similarity) and at a minor degree with sop3 (46\% identity and $71 \%$ similarity) [21]. This protein was never described in rape. It will be interesting to characterize the kinetic properties of $B$. napus sterol dehydrogenase, determine its specificity using labeled steroids as model substrates and classify this protein among the steroid dehydrogenases family.

Oleosins, the major proteins of oil bodies (75\%), were poor candidates for bidimensional (2D) electrophoresis due to their very alkaline $\mathrm{pl}$ and their low solubility in aqueous medium. However, oleosin corresponding to contig 156533 has a lower pl. So, it will be interesting to attempt to separate oleosins using 2D electrophoresis. To date, no caleosin was identified in our experiments using proteomic technique. However, ESTs database reveals the presence of one gene encoding at least one protein very homologous to $A$. thaliana caleosin. The use of specific antibody could be considered to verify this hypothesis.

Acknowledgments. Authors wish to thank C. Gaillard (UR, Biopolymères, Interactions et Assemblages, INRA, Nantes) for electronic microscopy measurements, Genoplante for free access to the rapeseed ESTS database and O. Lapierre and D. Tristant (Centre d'Etude et de Recherche sur I'Economie et l'Organisation des Productions Animales) for the gift of rape seeds and financial support of a part of this work through the project "Produire du lait autrement ».

\section{REFERENCES}

1. JOLIVET P, ROUX E, D'ANDREA S, ET AL. Protein composition of oil bodies in Arabidopsis thaliana ecotype WS. Plant Physiol Biochem 2004; 42: 501-9.

2. MURPHY DJ. The biogenesis and functions of lipid bodies in animals, plants and microorganisms. Prog Lipid Res 2001; 40: 325-438.

3. MURPHY DJ, CUMMINS I. Seed oil-bodies: isolation, composition and role of oil-body apolipoproteins. Phytochem 1989; 28: 2063-9.
4. TZEN JTC, CAO Y-Z, LAURENT P, RATNAYAKE C, HUANG AHC. Lipids, proteins, and structure of seed oil bodies from diverse species. Plant Physiol 1993; 101: 267-76.

5. MURPHY DJ, KEEN JN, O'SULLIVAN JN, ET AL. A class of amphipathic proteins associated with lipid storage bodies in plants. Possible similarities with animal serum apolipoproteins. Biochim Biophys Acta 1991; 1088: 86-94.

6. LI M, SMITH LI, CLARK DC, WILSON R, MURPHY DJ. Secondary structures of a new class of lipid body proteins from oilseeds. / Biol Chem 1992; 267: 8245-53.

7. ROBERTS MR, HODGE R, ROSS JHE, ET AL. Characterization of a new class of oleosins suggests a male gametophyte-specific lipid storage pathway. Plant / 1993; 3: 629-36.

8. HILLS MJ, WATSON MD, MURPHY DJ. Targeting of oleosins to the oil bodies of oilseed rape (Brassica napus L.). Planta 1993; 189: 24-9.

9. HERNANDEZ-PINZON I, PATEL K, MURPHY DJ. The Brassica napus calciumbinding protein, caleosin, has distinct endoplasmic reticulum- and lipid body-associated isoforms. Plant Physiol Biochem 2001; 39: 615-22.

10. TZEN JTC, PENG C-C, CHENG D-J, CHEN ECF, CHIU JMH. A new method for seed oil body purification and examination of oil body integrity following germination. J Biochem (Tokyo) 1997; 121: 762-8.

11. MICHALSKI M-C, BRIARD V, MICHEL F. Optical parameters of milk fat globules for light scattering measurements. Lait 2001; 81: 787-96.

12. BROWSE I, MCCOURT PJ, SOMERVILLE CR. Fatty acid composition of leaf lipids determined after combined digestion and fatty acid methyl ester formation from fresh tissue. Anal Biochem 1986; 152: 141-5.

13. FOLCH J, LEES M, SLOANE-STANLY GH. A simple method for the isolation and purification of total lipids from animal tissues. J Biol Chem 1957; 226: 497-509.

14. LOWRY OH, ROSEBROUGH NJ, FARR AL, RANDALL RJ. Protein measurement with the Folin-Phenol reagents. / Biol Chem 1951; 193: 265-75.

15. LAEMMLI UK. Cleavage of structural proteins during the assembly of the head of bacteriophage TA. Nature 1970; 227: 680-5.

16. NEUHOFF V, AROLD N. Improved staining of proteins in polyacrylamide gels including isoelectric focusing gels with clear background at nanogram sensitivity using Coomassie Brilliant Blue G-250 and R-250. Electrophoresis 1988; 9: 255-62.

17. ROUQUIE D, LANCELOT M-E, KERBOUL G, ET AL. The Genoplante oilseed rape chip. 7th International Congress of Plant Molecular Biology. Barcelona, Spain, 2003.

18. MURPHY DJ. Storage lipid bodies in plants and other organisms. Prog Lipid Res 1990; 29: 299-324.

19. KEDDIE IS, HUEBNER G, SLOCOMBE SP, ET AL. Cloning and characterization of an oleosin gene from Brassica napus. Plant Mol Biol 1992; 19: 443-53.

20. KEDDIE J, EDWARDS E-W, GIBBONS T, SHAW C, MURPHY DJ. Sequence of an oleosin cDNA from Brassica napus. Plant Mol Biol 1992; 19: 1079-83.

21. LIN LJ, TZEN JT. Two distinct steroleosins are present in seed oil bodies. Plant Physiol Biochem 2004; 42: 601-8. 